\title{
WORK PRODUCTIVITY IN WINE FARMS IN SELECTED COUNTRIES OF THE EUROPEAN UNION
}

\author{
Tadeusz Filipiak, $\mathrm{PhD}^{1 *}$; Mariusz Maciejczak, $\mathrm{PhD}^{2^{* *}}$ \\ Faculty of Economic Sciences, Warsaw University of Life Sciences - SGGW \\ ${ }^{*}$ https://orcid.org/0000-0002-9397-7595 \\ **ttps://orcid.org/0000-0002-0630-5628
}

\begin{abstract}
In the European Union, one of the industries which is of great economic and market importance and accordingly is to a large extent dependent on quantity and quality of labour resources is viticulture and wine production. The main objective of the research was to determine the productivity of work in wine farms in selected EU countries in the years 2004-2017. It was found that there was an increase in labour productivity in wine farms in almost all countries selected for research. The largest increase was recorded for Czech, Portuguese and Bulgarian farms. Nevertheless, the highest productivity of work was characteristic for French, German, Austrian and Italian farms. Additionally together with the increase in the economic size of wine farms, the productivity of work increased too.
\end{abstract}

Key words: work productivity, wine farms, FADN, European Union

JEL codes: Q12, D24

\section{INTRODUCTION}

All production factors are involved in the production process (especially in agriculture they are: land, labour and capital as well as knowledge, which is also increasingly mentioned). However, more and more often it is indicated that the most important role is played by the effectiveness of using labour resources (Ruttan, 2002). The efficiency and competitiveness of a given sector, and in particular agriculture, depends on the level and the possibility of increasing work productivity (Sumanth, 1997). Thus, work efficiency is the main factor affecting the level of development of societies. At the same time, it should be remem- bered, however, that the impact of the labour factor on the efficiency and competitiveness of a given sector as well as performance of the individual farm is also determined by systemic factors, both endo- and exogenous (Lagakos and Waugh, 2013).

When analysing the agricultural sector in the European Union, it can be noticed that one of the industries which is of great economic and market importance and which is to a large extent dependent on significant labour resources is viticulture and wine production. The European Union as a whole, including in particular countries such as France, Italy and Spain, on the one hand, are leaders in the production and trade of wine, and on the other, they engage sig-

\footnotetext{
${ }^{1}$ Corresponding author: Nowoursynowska 166, 02-787 Warsaw, Poland, tadeusz_filipiak@sggw.pl,+4822 5934235

${ }^{2}$ Corresponding author: Nowoursynowska 166,02-787 Warsaw, Poland, mariusz_maciejczak@sggw.pl, +4822 5934235
} 
nificant labour resources in this sector (Dirksmeyer, Strohm and Garming, 2014). However, as research shows, the quality of the work provided and its productivity differ significantly with respect to the agricultural sector in the European Union. Therefore, it is advisable to address the efficiency of the wine sector in EU countries, in particular to determine the productivity of work in wine farms.

\section{THEORETICAL BACKGROUND}

In the agricultural sector in the European Union, a total of about 10 million professionally active people are employed, accounting for $4.4 \%$ of total employment. Of all 28 Member States, 7 in agriculture work almost three-quarters of all those employed in agriculture. They are: Germany, Bulgaria, Spain, France, Italy, Poland and Romania (Eurostat, 2018). According to research over the last twenty years, the total number of employed in agriculture has decreased, with simultaneous increase in labour productivity (Martin-Retortillo and Pinillia, 2012). As the main factor in the growth of labour productivity in agriculture, the most important is the significant increase in the use of other factors of production, in particular technical, from other sectors of the economy. According to Kusz and Misiak (2017), the technical work equipment is responsible for the increase in work efficiency in agriculture in over $60 \%$.

It should be also emphasized that the level of labour productivity in the European Union is various in particular Member States. According to Baer-Nawrocka (2010), this diversity results from both production and economic factors, i.e. the level of economic development, the level of capital utilization, and technical labour equipment; socio-political factors, including the political system, structural changes, agrarian culture, social capital; as well as the environmental factors. In addition, Jaroszewska and Pietrzykowski (2018) pay an attention for significant regional diversification of the labour productivity level within the Member States themselves. They point out that the level of differentiation is smaller in most of the old Member States (Greece is a significant exception) and fluctuates around the average for the country, and much larger in the new Member States.
Researchers also point to other factors that systematically improve agricultural productivity. These factors can be divided into two main exo- and endogenous categories. External factors - exogenous include those for which farmers individually have no direct influence. It has been shown that one of the main such factors is the general level of remuneration in the economy, including in particular in other production sectors (Bervidova, 2002; Góral and Rembisz, 2018). It has been found that the higher wages in other sectors of the economy, the more labour resources flows out of them to agriculture, thus increasing the productivity of people who have decided to stay. The second important factor affecting labour productivity is the state's policy towards agriculture (Dorward, 2013). As underlined by (Novotna and Volek, 2016), there is a convergence effect related to the use of subsidies. Along with the increase in support for agriculture, in particular of small farms, labour productivity increases in them (Bervidova, 2002). Jarka (2013) emphasizes that the rate of change in the agrarian structure is also an important exogenous factor. Along with the increase in the size of farms and the scale of production, work productivity increases. A systemic effect is revealed here, because such farms are usually more technologically advanced. It is worth noting that farms cultivating grapevines are influenced by these exogenous factors and the work efficiency in them is also conditioned on them. As shown by Galindro et al. (2018) or Goncharuk and Sellers-Rubio (2018) in the shaping of work productivity in wine farms the remuneration offered in other sectors of the economy plays a significant role.

However, the main role in determining labour productivity in agriculture is played by factors that are internal or endogenous. These include mainly the size of the farm. Takacs et al. (2008) research shows that along with the increase in the size of the farm, work productivity also increases. At the same time Novotna and Volek (2016) show that with the increase in the size group of farms, the internal diversity of labour productivity diminishes. Another key internal factor determining work efficiency in agriculture, in particular in wine farms, is the level of their technical and technological advancement. As studies by Tomsik et al. (2016) or Török and Tóth (2013) show, vineyard 
farms with a significant degree of technology implementation are characterized by higher work efficiency. In relation to agriculture in general, only a few researchers indicate the role of the knowledge factor in shaping work efficiency. This role is revealed in sectors that use knowledge intensively, also at the level of basic work. An example of such a sector are wine farms. The knowledge of those working in them influences not only the quality of the achieved results in the form of a valuable crop, but also the effectiveness of the work itself. Research by or Sellers-Rubio, Alampi-Sottini and Menghini (2016) or Goncharuk and Figurek (2017) showed that the higher the knowledge and awareness of the vineyard's farmers and employees, the higher their productivity.

\section{MATERIALS AND METHODS}

The main objective of the research was to determine the productivity of work in wine farms in selected EU countries in the years 2004-2017. Labour productivity was defined as the net value added (farm value net added) per 1 full-time employee (AWU - annual work unit). Net value added is the total production value reduced by intermediate consumption (direct and general economic costs), including depreciation and includes the balance of subsidies and taxes related to operating activities. The work productivity study was defined for selected EU countries, including on average for the whole EU, then broken down according to the economic size criterion on average both for the EU and selected EU countries. Due to the lack of data for some countries, a detailed analysis covered only selected countries.

The study uses data from the EU's agricultural accounting system (FADN). As part of this accounting, data for 14 countries were acquired in the audited period: Austria, Bulgaria, Croatia, Cyprus, Greece, Spain, France, Germany, Portugal, Romania, Slovenia, Hungary and Italy. Wine farms for research were separated according to the Year * Country * SIZ6 * TF8 typology (Type 3 Wine and 6 economy classes). There were applied simple descriptive statistics methods, including dynamics of changes using exponential regression analysis. In order to make the value in the accounts realistically, the consumer price index
(HICP) was taken into account. In order to eliminate variability in agriculture, average 3-year studies were used for research and comparisons.

\section{RESULTS AND DISCUSSION}

Labour productivity is the basic measure of the effectiveness of business entities management. Labour productivity is related to the best use of resources of agricultural holdings, including wine farms. Table 1 presents the productivity of work in selected wine farms in the years 2004-2017. In the analysed period, in EU countries a relative increase in labour productivity was recorded on average by $2.77 \%$. In absolute terms, the increase in labour productivity was, on average, 1.2 thous. EUR per 1 AWU. The labour productivity amounted on average to approx. 42.4 thous. EUR.

In the analysed period, an increase in labour productivity was recorded in almost all selected countries for research, with the exception of Greek holdings. On Greek farms, a decrease of approx. 3.39 thous. EUR on 1 AWU was recorded. In the analysed period, in relative terms the highest increase in labour productivity in wine farms was recorded for Czech farms (annual average of $8.90 \%$ ), then Portuguese (annual average of $5.93 \%$ and Bulgarian (average annual $4.88 \%$ ). On Spanish and Italian farms and in France, an increase of $3.70 \%, 3.43 \%$ and $2.31 \%$ respectively was recorded. The smallest increase in labour productivity was observed in Cypriot $(0.65 \%$ on average) and Greek (0.85\%) farms annually. In absolute terms, in the analysed period, the highest increase in labour productivity was recorded in Czech farms (annual average of 2.6 thous. EUR), French (annual average 1.68 thous. EUR) and Italian (annual average 1.3 thous. EUR) and German farms (annually by 1.24 thous. EUR).

The highest efficiency of work was characteristic for French farms (on average 72,106.7 EUR for 1 AWU), then German (average 54,697.9 EUR), Austrian (average of 39,905.4 EUR) and Italian (average 36,406.5 EUR). The lowest labour productivity was typical for Cypriot farms (on average 9,626.9 EUR), Bulgarian (on average 10,543.9 EUR) and Croatian (average 10,823.2 EUR). 
Proceedings of the 2019 International Scientific Conference 'Economic Sciences for Agribusiness and Rural Economy' No 3, Warsaw, 5-7 June 2019, pp. 76-83

Table 1. Labour productivity of specialist vineyards in 2004-2017 (thous. EUR)

\begin{tabular}{|l|c|c|c|c|c|c|c|c|}
\hline Country & 2004-2006 & 2007-2009 & $2010-2012$ & $2013-2015$ & $2016-2017$ & Average & $\begin{array}{c}\text { Absolute } \\
\text { change }\end{array}$ & $\begin{array}{c}\text { Average } \\
\text { annual } \\
\text { change } \\
(\%)\end{array}$ \\
\hline (BGR) Bulgaria & - & 2.47 & 4.24 & 7.82 & 5.26 & 10.54 & 2.79 & 4.88 \\
\hline (CYP) Cyprus & 4.06 & 9.51 & 6.14 & 5.91 & 8.66 & 9.63 & 4.60 & 0.65 \\
\hline (CZE) Czech Republic & 8.52 & 9.64 & 9.51 & 11.72 & 12.83 & 27.84 & 4.31 & 8.90 \\
\hline (DEU) Germany & 24.68 & 25.40 & 26.89 & 30.98 & 32.99 & 54.70 & 8.31 & 2.28 \\
\hline (ELL) Greece & 14.01 & 13.15 & 12.22 & 10.81 & 10.62 & 18.13 & -3.39 & 0.85 \\
\hline (ESP) Spain & 12.94 & 14.93 & 16.86 & 18.87 & 20.74 & 22.04 & 7.80 & 3.70 \\
\hline (FRA) France & 33.71 & 35.70 & 38.92 & 42.67 & 44.80 & 72.11 & 11.09 & 2.31 \\
\hline (HRV) Croatia & - & - & - & 3.58 & 4.28 & 10.82 & 7.24 & 4.01 \\
\hline (HUN) Hungary & 7.02 & 6.70 & 9.00 & 10.26 & 10.70 & 19.78 & 3.68 & 1.75 \\
\hline (ITA) Italy & 17.79 & 19.40 & 20.77 & 25.91 & 29.04 & 36.41 & 11.25 & 3.43 \\
\hline (OST) Austria & 18.10 & 20.34 & 21.82 & 17.38 & 18.97 & 39.91 & 0.87 & 2.84 \\
\hline (POR) Portugal & 6.72 & 7.87 & 9.89 & 11.42 & 12.00 & 15.44 & 5.28 & 5.93 \\
\hline (ROU) Romania & - & 6.26 & 6.40 & 7.84 & 9.71 & 11.77 & 3.45 & 4.41 \\
\hline (SVN) Slovenia & 4.45 & 9.36 & 6.30 & 3.76 & 6.34 & 16.10 & 1.89 & 3.04 \\
\hline (EU) European Union & 21.12 & 21.44 & 23.65 & 27.17 & 29.55 & 42.45 & 8.43 & 2.77 \\
\hline
\end{tabular}

Slovenia data since 2005, for Bulgaria and Romania since 2007 and Croatia since 2013 (entry into the EU).

Source: author's calculations based on FADN data.

Table 2 presents the work efficiency depending on the economic size of wine farms. In the analysed period in EU countries, work efficiency in wine farms increased on average from 21,777.82 to 29,789.42 EUR per 1 AWU, i.e. by 8,011.6 EUR. The average annual increase in work productivity in relative terms was approx. $3.2 \%$, while in absolute terms it was, on average, 802.62 EUR per 1 AWU. The coefficient of variability of work efficiency in the examined period was about $15.28 \%$. With the increase in the economic size of wine farms, labour productivity increased. The largest one was on wine farms in the sixth class of economic size. In 2017 in the sixth class of economic size, work efficiency per 1 AWU was 61,620.39 EUR for 1 AWU. The lowest economic efficiency was in the 1st class of economic size and this year it amounted to approx. 5,188.16 EUR for 1 AWU. In the wine farms distinguished in terms of economic size, there was an increase in work efficiency in almost all classes, with the exception of the first class. In the years 2004-2017 in the first class of economic size there was an average annual decrease by $-1.67 \%$. Labour productivity decreased from approx. 8,018 to 5,188.16 EUR for $1 \mathrm{AWU}$, that is by $-2,830.18$ EUR for $1 \mathrm{AWU}$. In the remaining classes of economic size in wine growing enterprises an increase was recorded, the highest being the sixth class (annual average of $3.49 \%$ ) and fourth (annual average of 1.95\%). In absolute terms, the highest increase in labour productivity was also in the sixth class, labour productivity increased on average by 1,755.71 EUR per 1 AWU. While in total, in the analysed period, labour productivity increased by 19,075.59 EUR per 1 AWU. The lowest coefficient of work efficiency variability was in the fifth $(9.37 \%)$ and fourth $(14.19 \%)$ classes. 
Proceedings of the 2019 International Scientific Conference 'Economic Sciences for Agribusiness and Rural Economy' No 3, Warsaw, 5-7 June 2019, pp. 76-83

Table 2. Labour productivity (farm net value added per 1 AWU) of specialist vineyards depending on the economic size in 2004-2017 (EUR)

\begin{tabular}{|c|c|c|c|c|c|c|c|}
\hline \multirow{2}{*}{ Year } & \multicolumn{6}{|c|}{ Economic size class } & \multirow{2}{*}{$\begin{array}{c}\text { Total } \\
\text { average }\end{array}$} \\
\hline & 1 & 2 & 3 & 4 & 5 & 6 & \\
\hline 2004 & 8018.34 & 11111.89 & 16832.39 & 21882.48 & 34925.57 & 42544.80 & 21777.82 \\
\hline 2005 & 4787.98 & 9599.85 & 15320.50 & 20315.26 & 34659.51 & 46475.53 & 20364.38 \\
\hline 2006 & 4742.67 & 11611.19 & 18542.56 & 21895.80 & 34587.06 & 43108.41 & 21223.14 \\
\hline 2007 & 5308.86 & 11720.59 & 18136.69 & 25048.61 & 39123.37 & 38744.70 & 22462.97 \\
\hline 2008 & 5638.06 & 12586.51 & 18709.86 & 22074.71 & 38083.71 & 40666.10 & 22905.16 \\
\hline 2009 & 3048.87 & 7269.95 & 10337.31 & 15762.65 & 31300.78 & 36765.46 & 18946.07 \\
\hline 2010 & 5925.10 & 8263.26 & 11839.40 & 18487.12 & 33160.74 & 50253.75 & 21473.41 \\
\hline 2011 & 6328.00 & 8821.66 & 13513.60 & 21628.67 & 37525.55 & 53850.12 & 23970.83 \\
\hline 2012 & 5197.29 & 13017.85 & 14028.55 & 22317.21 & 36728.46 & 47368.83 & 25508.28 \\
\hline 2013 & 3681.63 & 11212.36 & 14072.06 & 22057.10 & 35153.59 & 52150.35 & 24123.81 \\
\hline 2014 & 3350.60 & 11714.57 & 15565.78 & 25236.42 & 41063.84 & 60348.84 & 27679.88 \\
\hline 2015 & 5245.43 & 11748.67 & 16682.61 & 25333.27 & 42305.22 & 60766.99 & 29716.87 \\
\hline 2016 & 5175.18 & 12764.44 & 19006.08 & 28695.05 & 43648.57 & 59919.37 & 31255.61 \\
\hline 2017 & 5188.16 & 13540.52 & 18855.98 & 26588.50 & 40453.13 & 61620.39 & 29789.42 \\
\hline Absolute change & -2830.18 & 2428.63 & 2023.59 & 4706.02 & 5527.56 & 19075.59 & 8011.60 \\
\hline Average annual change $(\%)$ & -1.67 & 1.55 & 0.32 & 1.95 & 1.49 & 3.49 & 3.20 \\
\hline Regression coefficient & -98.13 & 172.55 & 47.63 & 457.86 & 570.95 & 1755.71 & 802.62 \\
\hline Coefficient of variation $(\%)$ & 23.70 & 16.41 & 16.90 & 14.19 & 9.37 & 16.91 & 15.28 \\
\hline
\end{tabular}

Economic size (thous. EUR): 1 - from 2 to $<8 ; 2$ - from 8 to $<25 ; 3$ - from 25 to $<50 ; 4$ - from 50 to $<100 ; 5$ - from 100 to $<500 ; 6-\geq 500$.

Source: author's calculations based on FADN data.

Table 3 presents labour productivity depending on the economic size in individual EU countries in two sub-periods, i.e. for the years 2004-2006 and 2015-2017 . As in the case of the average for EU countries, the increase in labour productivity in wine farms in particular countries occurred with the increase in economic size, for both 2004-2006 and 2015-2017. Which means that work productivity increases along with the economic size of wine farms. In the analysed period, it was also possible to observe an increase in labour productivity in the years 2015-2017 in relation to the years 2004-2006 in wine farms distinguished in terms of economic size in almost all countries selected for research, except for Greek farms. In Greek farms there was a decrease in labour productivity in wine farms in all economic size classes comparing these two sub-periods (both in the second and third class). In the analysed periods, the decline in labour productivity in individual classes was recorded in Hungarian holdings for the third grade (from 9,074.20 to $7,442.35$ EUR for 1 AWU) and in Italian holdings also for third class (from 19,488.44 to 18,468.11 EUR for 1 AWU). By far the highest labour productivity was observed in both sub-periods of Italian holdings (except for the third grade in 2015-2017), followed by French, German, Spanish and Austrian. 
Proceedings of the 2019 International Scientific Conference 'Economic Sciences for Agribusiness and Rural Economy' No 3, Warsaw, 5-7 June 2019, pp. 76-83

Table 3. Farm net value added per 1 AWU of specialist vineyards depending on the economic size in 2004-2017 (thous. EUR)

\begin{tabular}{|c|c|c|c|c|c|c|c|}
\hline \multirow{2}{*}{ Country } & \multirow{2}{*}{ Year } & \multicolumn{6}{|c|}{ Farms by economic size } \\
\hline & & 1 & 2 & 3 & 4 & 5 & 6 \\
\hline \multirow{3}{*}{ (DEU) Germany } & 2004-2006 & - & - & 20330.59 & 21331.07 & 26457.21 & 25940.30 \\
\hline & 2014-2017 & - & - & 26441.38 & 27873.87 & 37102.52 & - \\
\hline & change & - & - & 6110.78 & 6542.80 & 10645.32 & - \\
\hline \multirow{3}{*}{ (ELL) Greece } & 2004-2006 & 10916.41 & 13575.49 & 16519.64 & - & - & - \\
\hline & 2015-2017 & - & 9400.08 & 14251.32 & - & - & - \\
\hline & change & - & -4175.41 & -2268.32 & - & - & - \\
\hline \multirow{3}{*}{ (ESP) Spain } & 2004-2006 & 6650.06 & 12334.33 & 19996.66 & 24812.96 & 30966.23 & - \\
\hline & 2015-2017 & - & 16902.27 & 20427.73 & 28695.24 & 34791.55 & - \\
\hline & change & - & 4567.94 & 431.07 & 3882.29 & 3825.32 & - \\
\hline \multirow{3}{*}{ (FRA) France } & 2004-2006 & - & - & 11888.56 & 20428.44 & 35881.19 & 50208.01 \\
\hline & 2015-2017 & - & - & 18586.06 & 27342.08 & 42965.20 & 61956.79 \\
\hline & change & - & - & 6697.50 & 6913.64 & 7084.01 & 11748.78 \\
\hline \multirow{3}{*}{ (HUN) Hungary } & 2004-2006 & 2665.56 & 9916.72 & 9074.20 & - & - & - \\
\hline & 2015-2017 & 6264.37 & 10862.60 & 7542.35 & - & - & - \\
\hline & change & 3598.81 & 945.88 & -1531.85 & - & - & - \\
\hline \multirow{3}{*}{ (ITA) Italy } & 2004-2006 & 5337.97 & 10942.43 & 19488.44 & 27099.22 & 40808.91 & 43997.28 \\
\hline & 2015-2017 & - & 11726.29 & 18468.11 & 28730.41 & 48648.49 & 68289.58 \\
\hline & change & - & 783.86 & -1020.33 & 1631.19 & 7839.59 & 24292.30 \\
\hline \multirow{3}{*}{ (OST) Austria } & 2004-2006 & - & - & 8022.89 & 16267.54 & 24074.68 & - \\
\hline & 2015-2017 & - & - & 17215.07 & 19733.86 & 36430.88 & - \\
\hline & change & - & - & 9192.18 & 3466.32 & 12356.21 & - \\
\hline \multirow{3}{*}{ (POR) Portugal } & 2004-2006 & 3238.85 & 6459.19 & 6561.56 & - & - & - \\
\hline & 2015-2017 & 9100.91 & 11114.73 & 12930.86 & - & - & - \\
\hline & change & 5862.06 & 4655.54 & 6369.30 & - & - & - \\
\hline \multirow{3}{*}{$\begin{array}{l}\text { (EU) European } \\
\text { Union }\end{array}$} & 2004-2006 & 5849.66 & 10774.31 & 16898.48 & 21364.51 & 34724.05 & 44042.91 \\
\hline & 2015-2017 & 5202.92 & 12684.54 & 18181.56 & 26872.27 & 42135.64 & 60768.92 \\
\hline & change & -646.74 & 1910.23 & 1283.07 & 5507.76 & 7411.59 & 16726.00 \\
\hline
\end{tabular}

Economic size (thous. EUR): 1 - from 2 to $<8 ; 2$ - from 8 to $<25 ; 3$ - from 25 to $<50 ; 4$ - from 50 to $<100 ; 5$ - from 100 to $<500 ; 6-\geq 500$.

Source: author's calculations based on FADN data. 


\section{CONCLUSIONS}

Based on the research, the following conclusions were found. Labour productivity is a basic measure of the effectiveness of production of goods and services, and testifies to the level of economic development of given economies, sectors and business entities, including wine farms. In the years 2004-2017 there was an increase in labour productivity in wine farms in almost all countries selected for research, except for Greek farms. The largest increase in the analysed period was recorded for Czech, Portuguese and Bulgarian farms. Nevertheless, the highest productivity of work was characteristic for French, German, Austrian and Italian farms. Together with the increase in the economic size of wine farms, the productivity of work increased. The largest increase was recorded in the largest farms. In the smallest (first class) farms, a decline in labour productivity was noted during the period under consideration. Therefore, the largest farms have a chance to grow. Therefore, it seems advisable to increase support for economically smaller farms.

\section{Acknowledgements}

This paper is based on the results of the project VITISMART (Toward a sustainable viticulture: Improved grapevine productivity and tolerance to abiotic and biotic stresses by combining resistant cultivars and beneficial microorganisms). The financing of this project by ERA-NET CO-FUND FACCE SURPLUS program through Polish National Centre for Research and Development (NCBiR) is acknowledged.

\section{REFERENCES}

1. Baer-Nawrocka, A. (2010). Zasoby pracy jako przesłanka konkurencyjności rolnictwa nowych krajów członkowskich Unii Europejskiej [Labour Force as an Evidence of the Competitiveness of Agriculture in the New European Union Member States]. Annals of the Polish Association of Agricultural and Agribusiness Economists, 10 (1), pp. 16-22.

2. Bervidova, L. (2002). Labour productivity as a factor of sustainable economic development of the CR agriculture. Agricultural Economics, 48 (2), pp. 55-59.
3. Dirksmeyer, W., Strohm, K., Garming, H. (2014). Competitiveness of Wine Grape Production - Updated results. Thünen Institute of Farm Economics, Braunschweig.

4. Dorward, A. (2013). Agricultural labour productivity, food prices and sustainable development impacts and indicators. Food Policy, 39, pp. 40-50.

5. Eurostat (2018). Farmers in the EU - statistics 2017.

6. Galindro, A., Santos, M., Santos, C., Marta-Costa, A., Matias, J., Cerveira, A. (2018). Wine productivity per farm size: A maximum entropy application. Wine Economics and Policy, 7 (1), pp. 77-84.

7. Goncharuk, A.G., Figurek, A. (2017). How efficient is winemaking in Eastern Europe. NEW MEDIT, 2, pp. 64-72.

8. Goncharuk, A.G., Sellers-Rubio, R. (2018). West vs East: How Different Is Performance in EURpean Winemaking. Journal of Applied Management and Investments, 7 (4), pp. 185-200.

9. Góral, J., Rembisz, W. (2018). Remunerations and labour productivity in agriculture against a background of other economy sectors. Acta Scientiarum Polonorum. Oeconomia, 17 (1), pp. 49-58.

10. Jarka, S. (2013). Ekonomiczna i społeczna wydajność pracy $\mathrm{w}$ przedsiębiorstwach rolniczych [Economic and social work efficiency in agricultural enterprises]. In: Proceedings of IX Congress of Polish Economists, Warsaw 28-29.11.2013.

11. Jaroszewska, J., Pietrzykowski, R. (2018). Dynamics of labour productivity changes in agriculture at the regional level in selected European Union countries. Acta Scientiarum Polonorum. Oeconomia, 17 (2), pp. 59-68.

12. Kusz, D., Misiak, T. (2017). Wpływ technicznego uzbrojenia pracy i postępu technicznego na wydajność pracy w rolnictwie [Influence of work technical equipment and technical progres labour on efficiency in agriculture]. Annals of the Polish Association of Agricultural and Agribusiness Economists, 19 (2), pp. 145-150.

13. Lagakos, D., Waugh, M. (2013). Selection, Agriculture, and Cross-Country Productivity Differences. American Economic Review, 103 (2), pp. 948-80.

14. Martin-Retortillo, M., Pinillia, V. (2012). Why did agricultural labour productivity not converge in Europe from 1950 to 2005? EHES Working Papers in Economic History 25.

15. Novotna, M., Volek, T. (2016). The Significance of Farm Size in the Evaluation of Labour Productivity in Agriculture. Acta Universitatis Agriculturae et Silviculturae Mendelianae Brunensis, 64 (1), pp. 333-340. 
Proceedings of the 2019 International Scientific Conference 'Economic Sciences for Agribusiness and Rural Economy' No 3, Warsaw, 5-7 June 2019, pp. 76-83

16. Ruttan, V.W. (2002). Productivity Growth in World Agriculture: Sources and Constraints. Journal of Economic Perspectives, 16 (4), pp. 161-184.

17. Sellers-Rubio, R., Alampi-Sottini, V., Menghini, S. (2016). Productivity growth in the winery sector: evidence from Italy and Spain. International Journal of Wine Business Research, 28 (1), pp. 59-75.

18. Sumanth, D.J. (1997). Total Productivity Management: A Systemic and Quantitative Approach to Compete in Quality, Price and Time. 1st edn. CRC Press.
19. Takacs, I., Baranyai, Z., Takacs, E., Takacs-Gyorgy, K. (2008). Change of labour productivity on fieldcrop farms in the UE countries from 1989 to 2005. Cereal Research Communications, 36, pp. 51-54.

20. Tomsik, P., Stojanova, H., Sedlo, J., Vajenerova, I. (2016). Factors of profitability of the grapes production. Agricultural Economic, 62, pp. 292-297.

21. Török, A., Tóth, J. (2013). Open characters of innovation management in the Hungarian wine industry. Agricultural Economics, 59, pp. 430-438. 